\title{
PENGARUH RETURN ON EQUITY, DEBT TO ASSET RATIO, DAN CURRENT RATIO TERHADAP KEBIJAKAN DIVIDEN PADA PERUSAHAAN SEKTOR INDUSTRI DASAR DAN KIMIA YANG LISTING DI BEI PERIODE 2013-2018
}

\author{
Ganda Sanjaya, Yeni Ariesa* \\ Fakultas Ekonomi, Universitas Prima Indonesia \\ Ganda.sanjaya96@yahoo.co.id, yeniariesa321@gmail.com
}

\begin{abstract}
The industrial sector is currently one of sectors that is able to accelerate economic growth. Because this sector has a role in overcoming problem of unemployment and creating an economy based on natural resources. Therefore, this sector supports national economic growth (www.economy.okezone.com). This study aims to examine and analyze influence of Return on Equity, Debt to Asset Ratio, and Current Ratio on Dividend Policy in basic and chemical industry companies listed in Indonesia Stock Exchange period 2013-2018. Processing data with SPSS 22 Software. Data analysis method used is descriptive statistics, classical assumption test, multiple linear regression analysis and hypothesis testing (simultaneous test, partial test and coefficient of determination). The results of study prove simultaneously Return On Equity, Debt to Asset Ratio and Current Ratio significantly influence Dividend Policy with F value of 15,641. Partially Return On Equity partially has no significant effect on Dividend Policy with $t$ value of $-3,378$, Debt to Asset Ratio partially has positive and significant effect on Dividend Policy with $t$ value of 4,611, Current Ratio partially has positive and significant effect on Policy Dividends with $t$ value of 5,400, with a coefficient of determination of $36.3 \%$. The remaining $63.7 \%$ is the influence of other variables.
\end{abstract}

Keywords: Return On Assets (ROA), Debt to Asset Ratio (DAR), Current Ratio (CR), Dividend Policy (DPR)

\section{PENDAhULUAN}

Perkembangan perusahaan yang sudah go public saat ini sudah semakin maju dan berkembang, dimana kondisi ini dapat dilihat semakin banyak perusahaan yang mendaftarkan perusahaannya di pasar modal untuk memperdagangkan saham bagi para investor. Untuk itu, dengan semakin ketatnya persaingan antara perusahaan yang sudah go public mendorong sebagian besar para investor untuk menginvestasikan dananya dalam bentuk saham perusahaan. Investasi yang telah dilakukan diharapkan setiap tahunnya dapat memberikan keuntungan yang optimal berupa pembagian dividen oleh perusahaan. Sektor industri saat ini merupakan salah satu sektor yang mampu mendorong percepatan pertumbuhan ekonomi. Pasalnya, sektor industri memiliki peranan dalam mengatasi masalah pengangguran dan menciptakan ekonomi berbasis sumber daya alam. Oleh karena itu, sektor industri sebagai sektor utama untuk mendukung pertumbuhan ekonomi nasional. (www.economy.okezone.com)

Kebijakan pembagian dividen (Devident Payout Ratio) yang dilakukan oleh tiap perusahaan pada umumnya berbeda-beda. Selain itu, tiap perusahaan juga mempunyai alasan dan pertimbangan tertentu apakah akan dilakukan pembagian dividen ataupun tidak sehingga pembagian dividen dapat dipengaruhi oleh berbagai faktor.

Return On Equity merupakan salah satu dari profitabilitas yang ada di perusahaan dimana rasio ini dapat menggambarkan sampai sejauh mana perusahaan mampu mengelola dan mengoptimalkan ekuitas ataupun modal yang ada untuk mendapatkan keuntungan. Untuk itu, setiap perusahaan mempunyai kebijakan berbeda-beda dalam menggunakan alokasi modal di perusahaan, apakah seluruhnya digunakan untuk membiayai aktivitas utama perusahaan maupun hanya digunakan sebagian saja dari modal yang dimiliki dalam membiayai aktivitas usaha sedangkan sebagian lagi menggunakan pinjaman dari kreditur. Dengan penggunaan modal pada aset yang produktif dan mampu mendatangkan perolehan laba maka hal ini menunjukkan bahwa pihak manajemen telah memahami bahwa modal yang 
tersedia haruslah dialokasi secara efektif dan efisien sehingga mampu memaksimalkan perolehan laba usaha karena perusahaan tidak tergantung dari penggunaan pinjaman dari kreditur atau bank. Dengan demikian, investor akan mengetahui bahwa investasi yang dilakukan diperusahaan benar-benar digunakan secara maksimal sehingga perolehan laba usaha nantinya akan digunakan sebagian oleh perusahaan untuk membagikan dividen pada para investor atas investasi yang ditanamkan di perusahaan.

Debt to Asset Ratio merupakan bagian dari solvabilitas yang dapat menggambarkan sampai sejauh mana aset yang dimiliki perusahaan dibiayai oleh hutang. Bila penggunaan pinjaman oleh perusahaan sudah efektif pada aset yang produktif dan menguntungkan maka hal ini nantinya memberikan informasi pada para investor bahwa pengalokasian dana pinjaman telah tepat sasaran dan keuntungan diperoleh dari penggunaan aset tersebut nanti diharapkan akan dibagikan dalam bentuk dividen pada para pemegang saham atau investor.

Current Ratio (CR) merupakan salah satu ukuran rasio likuiditas yang dihitung dengan membagi current assets (aktiva lancar) dengan currentliabitility (hutang/kewajiban lancar). Semakin besar Current Ratio menunjukkan semakin tinggi kemampuan perusahaan dalam memenuhi kewajiban jangka pendeknya (termasuk di dalamnya kewajiban membayar dividen kas yang terutang). Karena jika posisi likuiditas perusahaan kuat maka kemampuan perusahaan membayar dividen adalah besar. Berdasarkan analisis terhadap laporan keuangan sektor industri dasar dan kimia yang listing di Bursa Efek Indonesia diketahui fenomena pada PT Duta Pertiwi Nusantara Tbk yaitu laba bersih ditahun 2015-2016 mengalami peningkatan dari Rp 9.859.176.172,- menjadi Rp 10.009.391.103,- tetapi deviden mengalami penurunan dari Rp 4.540.310.892,- menjadi Rp 1.513.308.360,- dimana menurut teori seharusnya jika Return On Equity meningkat maka Devident Payout Ratio seharusnya meningkat. Kemudian, pada PT Asahimas Flat Glass Tbk yaitu total utang ditahun 2013-2014 mengalami penurunan dari Rp 778.666.000.000,- menjadi Rp 733.749.000.000,- tetapi deviden tidak mengalami perubahan yaitu Rp 34.720.000.000,- dimana menurut teori seharusnya jika Debt to Asset Ratio turun maka Devident Payout Ratio seharusnya meningkat. Selanjutnya, pada PT Semen Baturaja (Persero) Tbk yaitu aktiva lancar ditahun 2016-2017 mengalami peningkatan dari Rp 1.123.602.449.000,- menjadi Rp 1.358.329.865.000,tetapi deviden mengalami penurunan dari 64.768.605.000,- menjadi Rp 36.661.209.000,- dimana menurut teori seharusnya jika Current Ratio meningkat maka Devident Payout Ratio seharusnya meningkat.

\section{Indentifikasi Masalah}

1. Peningkatan Return On Equity tidak selalu diikuti dengan peningkatan Devident Payout Ratio pada perusahaan sektor industri dasar dan kimia yang listing di Bursa Efek Indonesia periode 2013 - 2018.

2. Penurunan Debt to Total Asset tidak selalu diikuti dengan peningkatan Devident Payout Ratio pada perusahaan sektor industri dasar dan kimia yang listing di Bursa Efek Indonesia periode 2013 - 2018.

3. Peningkatan Current Ratio tidak selalu diikuti dengan peningkatan Devident Payout Ratio pada perusahaan sektor industri dasar dan kimia yang listing di Bursa Efek Indonesia periode 2013 - 2018.

4. Peningkatan Return On Equity, penurunan Debt to Asset Ratio dan peningkatan Current Ratio tidak selalu diikuti dengan peningkatan Devident Payout Ratio pada perusahaan sektor industri dasar dan kimia yang listing di Bursa Efek Indonesia periode 2013 - 2018.

\section{Perumusan Masalah}

1. Bagaimana pengaruh Return On Equity terhadap kebijakan dividen pada perusahaan sektor industri dasar dan kimia yang listing di Bursa Efek Indonesia periode 2013 - 2018?

2. Bagaimana pengaruh Debt to Asset Ratio terhadap kebijakan dividen pada perusahaan sektor industri dasar dan kimia yang listing di Bursa Efek Indonesia periode 2013 -2018?

3. Bagaimana pengaruh Current Ratio terhadap kebijakan dividen pada perusahaan sektor industri dasar dan kimia yang listing di Bursa Efek Indonesia periode 2013 - 2018?

4. Bagaimana pengaruh Return On Equity, Debt to Asset Ratio dan Current Ratio terhadap kebijakan dividen pada perusahaan sektor industri dasar dan kimia yang listing di Bursa Efek Indonesia periode $2013-2018 ?$

\section{KAJIAN TEORITIS}

Menurut Fahmi (2016:82), Return On Equity disebut juga sebagai laba atas equity, rasio ini untuk mengkaji sejauh mana suatu perusahaan mempergunakan sumber daya yang dimiliki untuk mampu memberikan laba atas ekuitas. 


\section{Indikator Return On Equity}

Menurut Hery (2017:195), adapun rumus return on equity adalah : ROE $=\underline{\text { Laba bersih }}$

Total ekuitas

Menurut Hery (2017:166), Ratio utang terhadap aset merupakan rasio yang digunakan untuk mengukur perbandingan antara total utang dengan total aset.

\section{Indikator Debt to Asset Ratio}

Menurut Raharjaputra (2011:201), adapun rumus debt to asset ratio adalah:

Debt Ratio = Jumlah Utang

Jumlah asset

Menurut Murhadi (2015:57), rasio lancar adalah rasio yang biasa digunakan untuk mengukur kemampuan perusahaan memenuhi liabilitas jangka pendek yang akan jatuh tempo dalam waktu satu tahun.

\section{Indikator Current Ratio}

Menurut Harahap (2015:301), adapun rumus current ratio adalah :

$$
\text { Current Ratio }=\frac{\text { Aktiva Lancar }}{\text { Utang lancar }}
$$

Menurut Gumanti (2013:7), Kebijakan dividen adalah praktik yang dilakukan oleh manajemen dalam membuat keputusan pembayaran deviden, yang mencakup besaran rupiahnya, pola distribusi kas kepada pemegang saham.

\section{Indikator Kebijakan Deviden}

Menurut Sudana (2015:26), adapun rumus kebijakan deviden adalah :

$\mathrm{DPR}=\underline{\text { Divident per } \text { share }}$

Earning per share

\section{Penelitian Terdahulu}

Pamungkas, dkk (2017) meneliti pengaruh Return On Equity, Debt to Equity Ratio, Current Ratio, Earning Per Share dan Investment Opportunity Set terhadap Kebijakan Dividen. Teknik analisis data pada penelitian ini mengunakan analisis regresi linier berganda. Maka penelitian ini menujukan Return On Equity, Debt to Equity Ratio, dan earning per share tidak berpengaruh signifikan terhadap kebijakan dividen. Current Ratio dan investment opportunity set berpengaruh signifikan terhadap kebijakan dividen. Sarmento dan Dana (2016) meneliti Pengaruh Return On Equity, Current Ratio dan Earning Per Share terhadap Kebijakan Dividen pada Perusahaan Keuangan. Teknik analisis data dengan menggunakan analisis regresi linier berganda. Maka hasil analisis ditemukan bahwa Return On Equity, Current Ratio dan earning per share secara simultan berpengaruh positif dan signifikan terhadap kebijakan dividen. Return On Equity secara parsial berpengaruh positif namun tidak signifikan terhadap kebijakan dividen. Current Ratio secara parsial berpengaruh positif dan signifikan terhadap kebijakan dividen. earning per share secara parsial berpengaruh positif namun tidak signifikanterhadap kebijakan dividen Maulidah, dkk (2015) meneliti pengaruh Return on Asset, Current Ratio, Debt to Total Asset Ratio, Growth dan Firm Size terhadap Divident Payout Ratio (Studi pada Perusahaan BUMN yang Terdaftar di BEI Tahun 2009-2013). Teknik analisis yang digunakan adalah analisis regresi linier berganda. Maka hasil analisis ditemukan bahwa secara simultan variabel independen berpengaruh secara signifikan terhadap dividend payout ratio. Secara parsial, variabel ROA dan firm size berpengaruh positif tidak signifikan terhadap Dividend Payout Ratio, variabel Debt to Total Asset Ratio, dan Growth berpengaruh negatif tidak signifikan pada Dividend Payout Ratio, variabel Current Ratio berpengaruh positif signifikan pada Dividend Payout Ratio. 


\section{Pengaruh Return On Equity Terhadap Kebijakan Deviden}

Menurut Sudana (2015:197), Perusahaan hanya akan meningkatkan dividend payout ratio, jika pendapatan perusahaan meningkat dan perusahaan merasa mampu untuk mempertahankan kenaikan pendapatan tersebut dalam jangka panjang.

\section{Pengaruh Debt to Asset Ratio Terhadap Kebijakan Deviden}

Menurut Gumanti (2013:5), Perusahaan dengan leverage keuangan yang tinggi akan cenderung memiliki dividen yang rendah, karena jika dividen yang dibayarkan tinggi maka kondisi tersebut dapat dianggap bahwa perusahaan sudah menjanjikan komitmen baru yang secara financial tentu akan sangat mengganggu kestabilan keuangan perusahaan, khususnya beban biaya tetap.

\section{Pengaruh Current Ratio Terhadap Kebijakan Deviden}

Menurut Horne (2010:282), likuiditas perusahaan yang diukur oleh Current Ratio merupakan pertimbangan utama dalam banyak keputusan dividen, karena apabila dividen menunjukkan arus kas keluar makin besar posisi kas dan keseluruhan likuiditas perusahaan, maka semakin besar kemampuan perusahaan untuk membayarkan dividen.

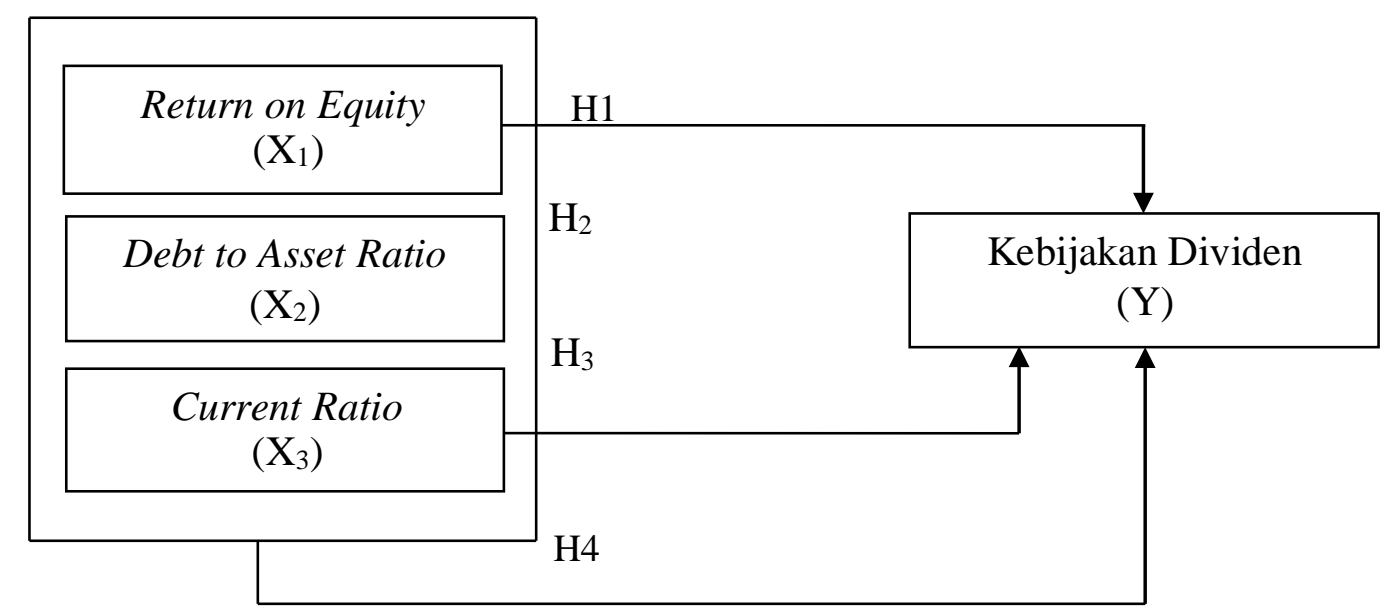

\section{Gambar 1. Kerangka Konseptual}

\section{Hipotesis :}

H1: Return On Equity berpengaruh secara parsial terhadap kebijakan dividen pada perusahaan sektor industri dasar dan kimia yang listing di Bursa Efek Indonesia periode 2013-2018

$\mathrm{H}_{2}$ : Debt to Asset Ratio berpengaruh secara parsial terhadap kebijakan dividen pada perusahaan sektor industri dasar dan kimia yang listing di Bursa Efek Indonesia periode 2013-2018

H3: Current Ratio berpengaruh secara parsial terhadap kebijakan dividen pada perusahaan sektor industri dasar dan kimia yang listing di Bursa Efek Indonesia periode 2013-2018

H4: Return On Equity, Debt to Asset Ratio dan Current Ratio berpengaruh secara simultan terhadap kebijakan dividen pada perusahaan sektor 5ndustry dasar dan kimia yang listing di Bursa Efek Indonesia periode 2013-2018

Penelitian ini dilakukan pada perusahaan sektor industri dasar dan kimia periode 2013-2018 dengan mengakses melalui situs www.idx.com. Penelitian dilakukan dari bulan September 2017 s.d. Maret 2019.

\section{METODE}

Menurut Sugiyono (2012:35) pendekatan penelitian yang digunakan dalam penelitian ini adalah pendekatan kuantitatif yaitu sebagai metode penelitian yang berlandaskan pada filsafat positifisme, digunakan untuk meneliti pada populasi atau sampel tertentu, pengumpulan data menggunakan instrument penelitian, analisis data bersifat kuantitatif / statistic, dengan tujuan untuk menguji hipotesis yang telah ditetapkan. Jenis penelitian ini adalah deskriptif kuantitatif. Menurut Sugiyono (2012:36) jenis 
penelitian deskriptif kuantitatif adalah jenis penelitian yang dimana data yang telah terkumpul dianalisis secara kuantitatif dengan menggunakan metode statistik deskriptif sehingga dapat disimpulkan hipotesis yang telah ditetapkan terbukti atau tidak.

Menurut Sugiyono (2012:148) menyatakan bahwa "Populasi adalah wilayah generalisasi yang terdiri dari objek/subjek yang mempunyai kualitas dan karakteristik tertentu yang ditetapkan oleh peneliti untuk dipelajari dan kemudian ditarik kesimpulannya." Dalam penelitian ini yang menjadi populasi adalah perusahaan sektor industri dasar dan kimia yang listing di Bursa Efek Indonesia periode 20132018 yang berjumlah 70 perusahan (lampiran). Menurut Sugiyono (2012:149), sampel merupakan bagian dari jumlah dan karakteristik yang dimiliki oleh populasi tersebut. Menurut Sujarweni (2015:88), sampling purposive adalah teknik penentuan sampel dengan pertimbangan atau kriteria-kriteria tertentu. Berikut ini kriteria pengambilan sampel penelitian adalah :

1. Perusahan sektor industri dasar dan kimia yang listing di Bursa Efek Indonesia pada tahun 2013 - 2018

2. Perusahaan sektor industri dasar dan kimia yang mempublikasikan laporan keuangan secara lengkap di Bursa Efek Indonesia pada tahun 2013-2018

3. Perusahaan sektor industri dasar dan kimia yang menghasilkan laba selama tahun 2013-2018

4. Perusahaan sektor industri dasar dan kimia yang membagikan dividen selama tahun 2013-2018

5. Berdasarkan hasil penelitian dengan kriteria diatas, maka didapatkan sampel sebanyak 13 perusahaan. Dapat dijelaskan bahwa terdapat 13 perusahaan yang dalam periode 6 tahun pengamatan dengan sebanyak 78 laporan keuangan pengamatan pada perusahaan sektor industri dasar dan kimia di Bursa Efek Indonesia pada periode 2013-2018

Tabel 1.

Defenisi Operasional Variabel Penelitian

\begin{tabular}{|c|c|c|c|c|c|}
\hline No & Variabel & Definisi Operasional & \multicolumn{2}{|c|}{ Indikator } & Skala \\
\hline \multirow{4}{*}{1} & \multirow{4}{*}{$\begin{array}{l}\text { Return On } \\
\text { Equity } \\
\text { (X1) }\end{array}$} & \multirow{4}{*}{$\begin{array}{l}\text { Return On Equity untuk mengkaji sejauh mana } \\
\text { suatu perusahaan mempergunakan sumber daya } \\
\text { yang dimiliki untuk mampu memberikan laba } \\
\text { atas ekuitas } \\
\text { sumber: Fahmi (2016) }\end{array}$} & & & \multirow{4}{*}{ Rasio } \\
\hline & & & \multirow[t]{2}{*}{ Return On Equity } & Laba Bersih & \\
\hline & & & & Total Equitas & \\
\hline & & & \multicolumn{2}{|l|}{ Sumber: Hery (2017) } & \\
\hline \multirow[t]{3}{*}{2} & $\begin{array}{c}\text { Debt to } \\
\text { Asset Ratio }\end{array}$ & $\begin{array}{l}\text { Debt to Asset Ratio merupakan rasio yang } \\
\text { digunakan untuk mengukur perbandingan antara }\end{array}$ & Debt & Jumlah Utang & \multirow{3}{*}{ Rasio } \\
\hline & & Sumber: Hery (2017) & Ratio & Jumlah Aset & \\
\hline & & & Sumber: Raharjaput & $(2011)$ & \\
\hline \multirow[t]{4}{*}{3} & \multirow{4}{*}{$\begin{array}{c}\text { Current } \\
\text { Ratio }\left(\mathrm{X}_{3}\right)\end{array}$} & \multirow{4}{*}{$\begin{array}{l}\text { Current Ratio adalah rasio yang biasa digunakan } \\
\text { untuk mengukur kemampuan } \\
\text { perusahaan memenuhi liabilitas jangka pendek } \\
\text { yang akan jatuh tempo dalam waktu satu tahun. } \\
\text { Sumber: Murhadi (2013) }\end{array}$} & & & \multirow{4}{*}{ Rasio } \\
\hline & & & $\begin{array}{l}\text { Current } \\
\text { Ratio }\end{array}=$ & Aktiva Lancar & \\
\hline & & & & an & \\
\hline & & & Sumber : Harahap (2 & 13) & \\
\hline \multirow[t]{3}{*}{4} & \multirow{3}{*}{$\begin{array}{l}\text { Dividen } \\
\text { (Y) }\end{array}$} & \multirow{3}{*}{$\begin{array}{l}\text { Kebijakan dividen adalah praktik yang dilakukan } \\
\text { oleh manajemen dalam membuat keputusan } \\
\text { pembayaran deviden, yang mencakup besaran } \\
\text { rupiahnya, pola distribusi kas kepada pemegang } \\
\text { saham. } \\
\text { Sumber: Gumanti (2013:7) }\end{array}$} & & & \multirow{3}{*}{ Rasio } \\
\hline & & & $\frac{\text { Dividend }}{E e}$ & $\begin{array}{l}\text { Dividend per } \\
\quad \text { share Payout =. } \\
\text { Ratio } \\
\text { Irning per } \\
\quad \text { share }\end{array}$ & \\
\hline & & & Sumber : Sudana (20 & & \\
\hline
\end{tabular}




\section{Uji Normalitas}

Menurut Ghozali (2016:154) uji normalitas bertujuan untuk menguji apakah dalam model regresi, variabel penggangu atau residual berdistribusi normal.

\section{Uji Multikolonieritas}

Menurut Ghozali (2016:103) uji multikolinearitas bertujuan untuk menguji apakah model regresi ditemukan adanya korelasi antar variabel bebas(independen). Model regresi yang baik seharusnya tidak terjadi korelasi antar variabel independen.

\section{Uji Autokorelasi}

Menurut Ghozali (2016:107-108) uji autokorelasi bertujuan untuk menguji apakah dalam suatu model regresi linier ada korelasi antar kesalahan pengganggu pada periode $t$ dengan kesalahan pada periode $\mathrm{t}-1$.

\section{Uji Heteroskedastisitas}

Menurut Ghozali (2016:134) uji heteroskedastisitas bertujuan untuk menguji apakah dalam model regresi terjadi ketidaksamaan variabel residual dari satu pengamatan ke pengamatan lain.

\section{Model Analisis Data}

Menurut Sugiyono (2012:277), menyatakan model analisis data dalam penelitian ini merupakan analisis regresi berganda digunakan untuk meramalkan bagaimana keadaan variabel dependen, bila dua atau lebih variabel independen sebagai faktor prediktor dimanipulasi

\section{Koefisien Determinasi $\left(\mathbf{R}^{2}\right)$}

$$
\mathrm{Y}=\mathrm{a}+\mathrm{b}_{1} \mathrm{X}_{1}-\mathrm{b}_{2} \mathrm{X}_{2}+\mathrm{b}_{3} \mathrm{X}_{3}+\mathrm{e}
$$

Menurut Ghozali (2016:95), koefisien determinasi pada intinya mengukur seberapa jauh kemampuan model dalam menerangkan variasi variabel dependen. Nilai koefisien determinasi adalah antara nol atau satu. Nilai koefisien determinasi yang kecil berarti kemampuan variabel-variabel independen dalam menjelaskan variasi variabel dependen amat terbatas.

\section{Pengujian Hipotesis Secara Simultan (Uji F)}

Menurut Ghozali (2016:96) uji statistik F pada dasarnya menunjukkan apakah semua variabel independen atau bebas yang dimasukkan dalam model mempunyai pengaruh secara bersama-sama terhadap variabel dependen atau terikat.

\section{Pengujian Hipotesis Secara Parsial (Uji t)}

Menurut Ghozali (2016:97) uji statistik t pada dasarnya menunjukkan seberapa jauh pengaruh satu variabel independen atau bebas secara individual dalam menerangkan variasi variabel dependen atau terikat.

\section{HASIL PENELITIAN DAN PEMBAHASAN}

\section{Hasil Statistik Deskriptif}

Statistik deskriptif memberikan gambaran mengenai minimum,maksimum, total nilai, nilai rata-rata dan standar deviasi data yang digunakan dalam penelitian. Berikut ini merupakan data statistik dari seluruh data variabel yang digunakan dalam penelitian ini:

Tabel 2.

Descriptive Statistics

\begin{tabular}{|l|r|r|r|r|r|}
\hline & $\mathrm{N}$ & Minimum & Maximum & Mean & Std. Deviation \\
\hline ROE & 78 &, 002 &, 309 &, 11429 &, 063552 \\
DAR & 78 &, 071 &, 837 &, 30444 &, 182273 \\
CR & 78 &, 993 & 15,165 & 3,94400 & 3,096463 \\
DPR & 78 &, 001 & 2,264 &, 37878 &, 486199 \\
Valid N (listwise) & 78 & & & & \\
\hline
\end{tabular}

Sumber : Data diolah, 2019

Pada tabel 2 menunjukkan bahwa $\mathrm{N}$ atau jumlah data pada setiap variabel yang valid adalah 78 . Dari 78 buah sampel data Return On Equity, nilai minimum Return On Equity sebesar 0,002 yang berada pada PT Asahimas Flat Glass Tbk pada tahun 2018. Nilai maksimum Return On Equity sebesar 0,309 
pada PT Arwana Citramulia Tbk pada tahun 2013. Nilai rata-rata Return On Equity adalah 0,11429 dengan standar deviasi 0,063552. Dari 78 sampel data Debt to Asset Ratio, nilai minimum Debt to Asset Ratio sebesar 0,071 yang berada pada PT Semen Baturaja (Persero) Tbk pada tahun 2014. Nilai maksimum Debt to Asset Ratio sebesar 0,837 pada PT Indal Aluminium Industry Tbk pada tahun 2014. Nilai rata-rata Debt to Asset Ratio adalah 0,30444 dengan standar deviasi 0,182273. Dari 78 sampel data Current Ratio, nilai minimum Current Ratio sebesar 0,993 yang berada pada PT Indal Aluminium Industry Tbk pada tahun 2017. Nilai maksimum Current Ratio sebesar 15,165 pada PT Duta Pertiwi Nusantara Tbk pada tahun 2016. Nilai rata-rata Current Ratio adalah 3,94400 dengan standar deviasi 3,096463. Dari 78 sampel data Divident Payout Ratio, nilai minimum Divident Payout Ratio sebesar 0,001 yang berada pada PT Arwana Citramulia Tbk pada tahun 2015. Nilai maksimum Divident Payout Ratio sebesar 2,264 pada PT Lion Metal Works Tbk pada tahun 2017. Nilai rata-rata Divident Payout Ratio adalah 0,37878 dengan standar deviasi 0,486199.

\section{IV.2 Hasil Uji Asumsi Klasik}

Penelitian ini memiliki jumlah sampel (N) sebanyak 78. Pada saat melakukan uji asumsi klasik, terjadi suatu permasalahan pada uji Normalitas yaitu dimana nilai signifikan lebih kecil dari 0,05 maka peneliti melakukan transformasi LN untuk mengatasi masalah uji normalitas.

\section{Uji Normalitas}

Uji normalitas bertujuan untuk menguji apakah model regresi, variable penganggu dan residual memiliki distribusi normal. Uji normalitas dapat dilihat dengan dua cara yaitu analisis grafik dan uji statistik.

\section{Analisis Grafik}

Salah satu cara termudah untuk melihat normalitas residual adalah dengan melihat grafik histogram yang membandingkan antara data observasi dengan distribusi yang mendeteksi distribusi normal. Pada grafik normal probability plot berdistribusi normal akan membantuk satu garis lurus diagonal, dan ploting data residual normal maka garis yang menggambarkan dan sesungguhnya akan mengikuti garis diagonalnya. Berikut ini adalah hasil uji analisis grafik Histogram sebelum di transformasi dan setelah di transformasi :

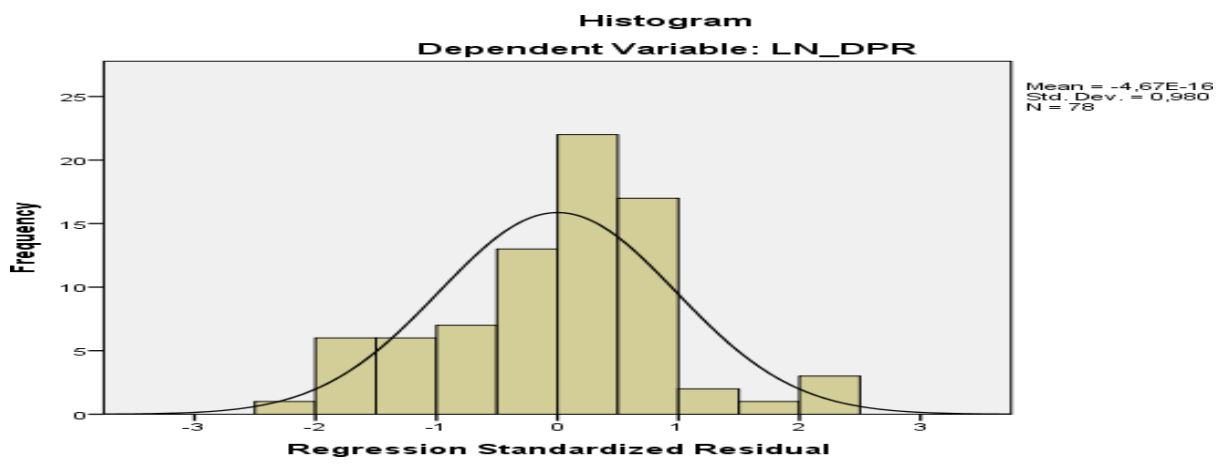

Gambar 2.

Uji Normalitas Histogram Sebelum Transformasi Data Sumber : Data diolah, 2019

Pada gambar 2 menunjukkan grafik histogram berdistribusi tidak normal. Hal ini dapat dilihat dari grafik histogram yang menunjukkan data tidak simestris dan menceng ke kiri. 


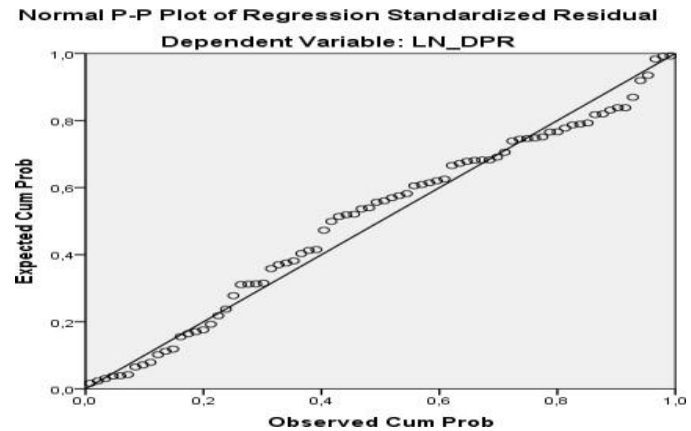

Gambar 3.

Uji Normalitas P-P Plot Setelah Transformasi Data

Sumber : Data diolah, 2019

Pada gambar 3 grafik P-Plot data berdistribusi normal akan membentuk satu garis lurus diagonal. Jika distribusi data residual normal, maka titik-titik pada grafik normal probability-plot menyebar mengikuti arah garis diagonalnya. Dari grafik normal probability- plot dan histogram pada gambar setelah ditransformasi dapat disimpulkan bahwa data berdistribusi secara normal.

2. Analisis statistik

Uji statistik lain yang dapat digunakan untuk menguji normalitas residual adalah uji statistik nonparametrik Kolmogorov-Smirnov (K-S). Pada uji kolmogorov-smirnov, pedoman yang digunakan dalam pengambilan keputusan adalah:

a. Jika nilai signifikansi $<0,05$ maka distribusi data residual tidak normal.

b. Jika nilai signifikansi $>0,05$ maka data residual berdistribusi normal.

Tabel 3.

One-Sample Kolmogorov-Smirnov Test

\begin{tabular}{|c|c|c|}
\hline & & Unstandardized Residual \\
\hline $\begin{array}{l}\mathrm{N} \\
\text { Normal Parameters }{ }^{\mathrm{a}, \mathrm{b}} \\
\text { Most Extreme Differences } \\
\text { Test Statistic } \\
\text { Asymp. Sig. (2-tailed) }\end{array}$ & $\begin{array}{l}\text { Mean } \\
\text { Std. Deviation } \\
\text { Absolute } \\
\text { Positive } \\
\text { Negative }\end{array}$ & $\begin{array}{r}78 \\
.0000000 \\
1,46605853 \\
, 091 \\
, 080 \\
-, 091 \\
, 091 \\
, 173^{\mathrm{c}}\end{array}$ \\
\hline
\end{tabular}

a. Test distribution is Normal.

b. Calculated from data.

Sumber : Data diolah, 2019

Hasil uji kolmogorov-smirnov setelah transformasi pada tabel 3 menunjukkan nilai signifikansi sebesar 0,173 berada diatas 0,05 berarti data berdistribusi normal. Hal ini dapat dilihat pada nilai Asymp.Sig. (2-tailed) 0,173 lebih besar dari 0,05 sehingga berdistribusi normal. Dengan demikian data pada penelitian ini berdistribusi normal dan dapat digunakan untuk melakukan uji lainnya karena memiliki nilai signifikan >0,05 ( $\mathrm{H} 0$ diterima).

\section{Uji Multikolonieritas}

Untuk mendeteksi ada atau tidaknya multikolonieriyas didalam model regresi dapat dilihat dari nilai tolerance dan Variance Inflation Factor (VIF) cara pengambilan keputusannya yaitu nilai tolerance $\geq 0,10$ atau sama dengan nilai VIF $\leq 10$. Berikut ini adalah hasil uji multikolnieritas sebelum ditransformasi dan setelah ditransformasi. 
Tabel 4.

Coefficients $^{\mathrm{a}}$

\begin{tabular}{|ll|r|c|}
\hline \multirow{2}{*}{ Model } & \multicolumn{2}{|c|}{ Collinearity Statistics } \\
\cline { 2 - 4 } & Tolerance & VIF \\
\hline 1 & LN_ROE &, 977 & 1,023 \\
& LN_DAR &, 226 & 4,428 \\
& LN_CR &, 224 & 4,474 \\
\hline
\end{tabular}

a. Dependent Variable: LN_DPR

Sumber : Data diolah, 2019

Pada tabel 4 diatas menunjukkan bahwa nilai tolerance yang diperoleh untuk variabel Return On Equity adalah sebesar 0,977, variabel Debt to Asset Ratio adalah sebesar 0,226 dan variabel Current Ratio adalah sebesar 0,224. Nilai VIF untuk variabel Return On Equity adalah 1,023, variabel Debt to Asset Ratio adalah 4,428, dan variabel Current Ratio sebesar 4,474. Jadi dapat disimpulkan tidak ada multikolonieritas antar variabel independen dalam model regresi.

\section{Uji Autokorelasi}

Uji autokorelasi bertujuan untuk menguji apakah dalam model regresi linear korelasi antara kesalahan penganggu pada periode $t$ dengan kesalahan pada t-1 (sebelumnya). Cara yang dapat digunakan untuk mendeteksi apakah terjadi autokorelasi atau tidak pada model regresi adalah dengan uji DurbinWatson.

Tabel 5.

Model Summary ${ }^{b}$

\begin{tabular}{l|l|}
\hline Model & \multicolumn{1}{|c|}{ Durbin-Watson } \\
\hline 1 & 2,037 \\
\hline a. Predictors: (Constant), LN_CR, LN_ROE, LN_DAR \\
b. Dependent Variable: LN_DPR
\end{tabular}

Sumber : Data diolah, 2019

Pada tabel 5 hasil pengolahan diperoleh nilai statistik DW $=2.037$, sementara dari tabel DW pada tingkat kekeliruan 5\% untuk jumlah variabel independen $=3$ dan jumlah pengamatan $n=78$ diperoleh batas bawah nilai tabel $(\mathrm{dl})=1,5535$ dan batas atasnya $(\mathrm{du})=1,7129$, sehingga nilai $4-\mathrm{du}=2,2871$. dapat diketahui bahwa nilai DW pada penelitian ini adalah $\mathrm{du}<\mathrm{d}<4$-du atau berada di antara 1,7129<2,037< 2,2871, maka dapat disimpulkan bahwa model persamaan regresi tersebut tidak mengandung masalah autokorelasi.

\section{Uji Heteroskedastisitas}

Uji heteroskedastisitas dapat dilihat dengan dua cara yaitu uji grafik Scatter Plot dan Uji White.

1. Scatterplot

Metode ini yaitu dengan cara melihat grafik scatterplot antara standardized predicted value (ZPRED) dengan studentized residual (SRESID). Ada tidaknya pola tertentu pada grafik scatterplot antara SRESID dan ZPRED dimana sumbu Y adalah Y yang telah diprediksi dan sumbu X adalah residual (Y prediksi - Y sesungguhnya).

Dasar pengambilan keputusan yaitu:

a. Jika ada pola tertentu, seperti titik-titik yang ada membentuk suatu pola tertentu yang teratur (bergelombang, melebar kemudian menyempit), maka terjadi heteroskedastisitas.

b. Jika tidak ada pola yang jelas, seperti titik-titik menyebar di atas dan di bawah angka 0 pada sumbu Y, maka tidak terjadi heteroskedastisitas.

Berikut ini hasil uji grafik scatter plot sebelum di transformasi: 


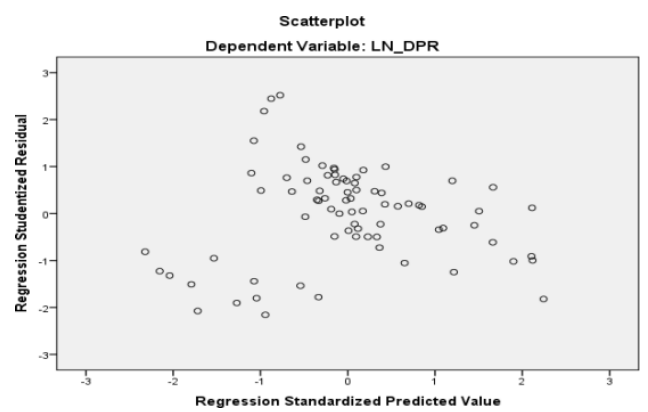

\section{Gambar 4. \\ Uji Heteroskedastisitas Grafik Scatterplot Setelah Transformasi Data \\ Sumber : Data diolah, 2019}

Pada gambar 4 menunjukkan tidak ada pola yang jelas, serta titik-titik menyebar diatas dan dibawah angka 0 pada sumbu Y, maka tidak terjadi heteroskedastisitas.

2. Uji White

Berikut ini hasil uji white sebelum di transformasi dan setelah transformasi :

Tabel 6.

Uji White Setelah Transformasi Data

Model Summary ${ }^{b}$

\begin{tabular}{|l|r|r|r|r|r|}
\hline Model & $\mathrm{R}$ & $\mathrm{R}$ Square & \multicolumn{1}{c|}{$\begin{array}{c}\text { Adjusted R } \\
\text { Square }\end{array}$} & $\begin{array}{c}\text { Std. Error of the } \\
\text { Estimate }\end{array}$ & Durbin-Watson \\
\hline 1 &, $529^{a}$ &, 280 &, 208 & 2,67089 & 2,205 \\
\hline
\end{tabular}

a. Predictors: (Constant), LN_ROE.LN_DAR.LN_CR, LN_ROE2, LN_DAR, LN_CR,

LN CR2, LN ROE, LN DAR2

b. Dependent Variable: RES2_2

Sumber : Data diolah, 2019

Pada tabel 6 diatas menunjukkan nilai R Square sebesar 0,280 dengan jumlah sampel 78 dan jumlah variabel ada 4 . Hasil chi-square hitung yaitu sebesar $(78 \times 0,280)=21,84$. Sedangkan hasil chisquare tabel dilihat dari pada urutan ke $78-4$ (variabel) $=74$ dengan tingkat 0,05 , maka diperoleh nilai pada tabel sebesar 95.08147. dengan demikian dapat disimpulkan tidak terjadi heterokedastisitas karena hasil chi-square hitung lebih kecil dari chi-square tabel $\left(\mathrm{C}^{2}\right.$ hitung $<\mathrm{C}^{2}$ tabel).

\section{Analisis Regresi Linear Berganda}

Tabel 7.

Coefficients $^{a}$

\begin{tabular}{|c|c|c|c|c|c|c|c|c|}
\hline \multirow{2}{*}{\multicolumn{2}{|c|}{ Model }} & \multicolumn{2}{|c|}{$\begin{array}{l}\text { Unstandardized } \\
\text { Coefficients }\end{array}$} & \multirow{2}{*}{$\begin{array}{c}\begin{array}{c}\text { Standardized } \\
\text { Coefficients }\end{array} \\
\text { Beta }\end{array}$} & \multirow[b]{2}{*}{$\mathrm{t}$} & \multirow[b]{2}{*}{ Sig. } & \multicolumn{2}{|c|}{$\begin{array}{l}\text { Collinearity } \\
\text { Statistics }\end{array}$} \\
\hline & & $B$ & Std. Error & & & & Tolerance & VIF \\
\hline \multirow[t]{4}{*}{1} & (Constant) & $-2,869$ & ,689 & & $-4,164$ & ,000 & & \\
\hline & LN_ROE &,- 703 & 208 &,- 311 & $-3,378$ & ,001 & ,977 & 1,023 \\
\hline & LN_DAR & 2,963 & ,643 & ,882 & 4,611 &, 000 & ,226 & 4,428 \\
\hline & LN_CR & 2,857 & ,529 & 1,039 & 5,400 & ,000 & ,224 & 4,474 \\
\hline
\end{tabular}

a. Dependent Variable: LN_DPR

Sumber : Data diolah, 2019

Berdasarkan tabel 7 maka diperoleh persamaan linear berganda hipotesis penelitian sebagai berikut:

$$
\text { LnDPR }=-2,869-0,703 \mathrm{LnROE}+2,963 \mathrm{LnDAR}+2,857 \mathrm{LnCR}
$$

Dari persamaan diatas dapat diartikan sebagai berikut:

1. Nilai konstanta $\alpha=-2,869$

Nilai konstan ini menunjukkan bahwa variabel bebas yaitu Return On Equity (X1), Debt to Asset 
Ratio (X2) dan Current Ratio (X3) dianggap konstan atau sama dengan 0, maka nilai Divident Payout Ratio pada perusahaan sektor industri dasar dan kimia yang listing di Bursa Efek Indonesia menurun sebesar $-2,869$.

2. Nilai $\beta 1$ Return On Equity (X1) memiliki koefisien regresi bertanda negatif sebesar - 0,703, dimana jika Return On Equity (X1) meningkat sebesar 1 satuan maka Divident Payout Ratio akan menurun sebesar $-0,703$.

3. Nilai $\beta 1$ Debt to Asset Ratio (X2) memiliki koefisien regresi bertanda positif sebesar 2,963, dimana jika Debt to Asset Ratio (X2) meningkat sebesar 1 satuan maka Divident Payout Ratio akan meningkat sebesar 2,963.

4. Nilai $\beta 3$ Current Ratio (X3) memiliki koefisien regresi bertanda positif sebesar 2,857, dimana jika Current Ratio (X3) meningkat 1 satuan maka Divident Payout Ratio akan meningkat sebesar 2,857.

\section{Koefisien Determinasi}

Koefisien determinasi $\left(\mathrm{R}^{2}\right)$ dilakukan untuk mengukur seberapa jauh kemampuan model dalam menerangkan variasi variabel dependen. Namun dalam penelitian ini digunakan nilai Adjusted $R^{2}$ untuk dapat mengevaluasi mana model terbaik. Tidak seperti $\mathrm{R}^{2}$, nilai adjusted $\mathrm{R}^{2}$ dapat naik atau turun apabila satu variabel indenpenden ditambahkan kedalam model. Nilai Adjusted $\mathrm{R}$ Square digunakan untuk mengukur seberapa besar pengaruh informasi Return On Equity, Debt to Asset Ratio dan Current Ratio terhadap Kebijakan Dividen pada perusahaan sektor industri dasar dan kimia yang listing di Bursa Efek Indonesia periode 2013-2018. Hasil perhitungannya adalah sebagai berikut:

Tabel 8.

Model Summary

\begin{tabular}{l|r|r|r|r|r|}
\hline Model & $\mathrm{R}$ & $\mathrm{R}$ Square & $\begin{array}{c}\text { Adjusted R } \\
\text { Square }\end{array}$ & $\begin{array}{c}\text { Std. Error of the } \\
\text { Estimate }\end{array}$ & Durbin-Watson \\
\hline 1 &, $623^{\mathrm{a}}$ &, 388 &, 363 & 1,49548 & 2,037 \\
\hline
\end{tabular}
a. Predictors: (Constant), LN_CR, LN_ROE, LN_DAR
b. Dependent Variable: LN_DPR
Sumber : Data diolah, 2019

Berdasarkan tabel 8 diperoleh nilai Adjusted R Square sebesar 0,363 atau 36,3\% yang berarti perubahan variabel Divident Payout Ratio dapat dijelaskan oleh variasi variabel Return On Equity, Debt to Asset Ratio dan Current Ratio, sedangkan sisanya sebesar 63,7\% merupakan variabel dari variabel bebas lain yang tidak diteliti dalam penelitian ini seperti Return On Asset., Debt to Equity Ratio, Cash Ratio, Quick Ratio.

\section{Pengujian Hipotesis Secara Simultan (Uji F)}

Tabel 9.

ANOVA $^{\mathrm{a}}$

\begin{tabular}{|ll|r|r|r|r|r|}
\hline Model & & Sum of Squares & df & Mean Square & F & Sig. \\
\hline 1 & Regression & 104,939 & 3 & 34,980 & 15,641 &, $000^{\mathrm{b}}$ \\
& Residual & 165,498 & 74 & 2,236 & & \\
& Total & 270,437 & 77 & & & \\
\hline
\end{tabular}

a. Dependent Variable: LN_DPR

b. Predictors: (Constant), LN_CR, LN_ROE, LN_DAR

Sumber : Data diolah, 2019

Berdasarkan tabel 9 dapat dilihat hasil Fhitung adalah sebesar 15,641 dengan tingkat signifikan 0,000 dan dengan menggunakan tabel $\mathrm{F}$ adalah df1 $=\mathrm{k}(4)-1=3$ dan df $2=\mathrm{n}(78)-\mathrm{k}(4)=74$ adalah 2,73, jadi nilai yang diperoleh Ftabel sebesar 2,73 maka hasilnya adalah Fhitung > Ftabel $(15,641>2,73)$ dengan tingkat signifikan $0,000<0,05$. Hal ini menunjukkan bahwa hasil hipotesis penelitian $\mathrm{H} 0$ ditolak dan Ha diterima artinya Return On Equity, Debt to Asset Ratio dan Current Ratio secara simultan berpengaruh positif dan signifikan terhadap Divident Payout Ratio. 


\section{Pengujian Hipotesis Secara Parsial (Uji t)}

Tabel 10.

Coefficients $^{\mathrm{a}}$

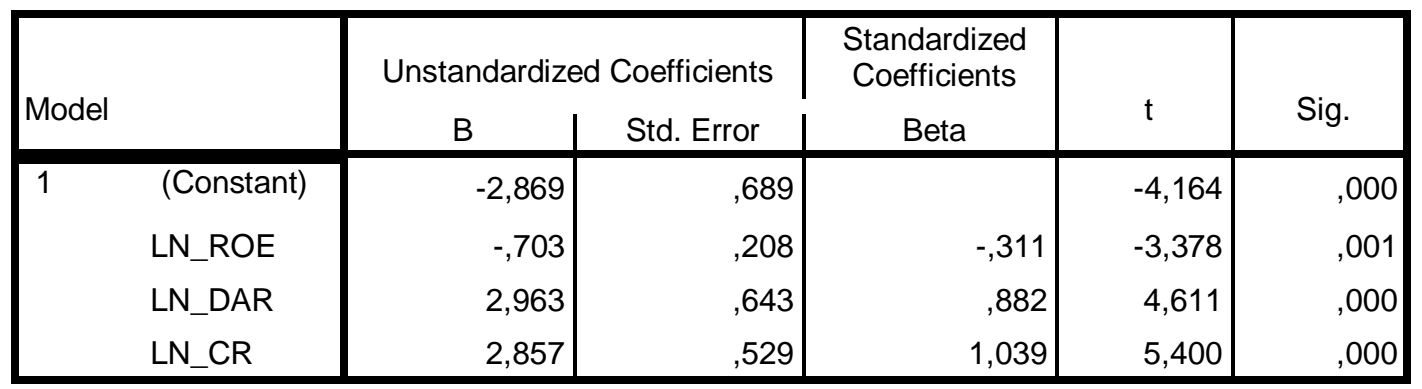

a. Dependent Variable: LN_DPR

Sumber : Data diolah, 2019

Dari tabel 10 hasil pengujian secara parsial diatas, dapat dilihat bahwa :

1. Pengaruh Return On Equity terhadap Divident Payout Ratio

Uji t digunakan untuk menguji signifikan konstanta dan setiap variabel independennya. Terlihat diatas bahwa variabel Return On Equity punyai nilai tabel sebesar 1,99254 (uji t $=\mathrm{n}(78)-\mathrm{k}(4)=$ 74), maka -thitung <-ttabel adalah $(-3,378<-1,99254)$ dengan signifikan $0,001<0,05$. Hal ini menunjukkan bahwa hasil hipotesis penelitian Ha ditolak dan $\mathrm{H}_{0}$ diterima artinya secara parsial Return On Equity tidak berpengaruh dan signifikan terhadap Devident Payout Ratio.

2. Pengaruh Debt to Asset Ratio terhadap Divident Payout Ratio

Variabel Debt to Asset Ratio mempunyai nilai tabel sebesar 1,99254, maka thitung < tabel adalah $(4,611>1,99254)$ dengan nilai signifikan $0,000<0,05$. Hal ini menunjukkan bahwa hasil hipotesis penelitian Ha diterima dan $\mathrm{H}_{0}$ ditolak artinya secara parsial Debt to Asset Ratio berpengaruh positif dan signifikan terhadap Divident Payout Ratio.

3. Pengaruh Current Ratio terhadap Divident Payout Ratio

Variabel Current Ratio mempunyai nilai tabel sebesar 1,99254, maka thitung > ttabel adalah $(5,400>1,99254)$ dengan nilai signifikan $0,00<0,05$. hal ini menunjukkan bahwa hasil hipotesis penelitian $\mathrm{Ha}$ diterima dan $\mathrm{H} 0$ ditolak artinya secara parsial Current Ratio berpengaruh positif dan signifikan terhadap Divident Payout Ratio.

\section{Pembahasan Hasil Penelitian}

Berdasarkan hasil uji secara parsial menunjukan bahwa Return On Equity tidak berpengaruh dan signifikan terhadap Divident Payout Ratio dan hasil penelitian ini tidak sejalan dengan teori Menurut Sudana (2015:197), Perusahaan hanya akan meningkatkan dividend payout ratio, jika pendapatan perusahaan meningkat dan perusahaan merasa mampu untuk mempertahankan kenaikan pendapatan tersebut dalam jangka panjang. Hasil penelitian ini sejalan dengan penelitian Pamungkas, dkk (2017) yang menyatakan bahwa secara parsial Return On Equity tidak berpengaruh signifikan terhadap Divident Payout Ratio. Pada penelitian ini secara parsial Return On Equity tidak berpengaruh dan signifikan terhadap Divident Payout Ratio. Sehingga pada Peusahaan tidak perlu memperhatikan kenaikan laba perusahaan, untuk melakukan pembayaran dividen Berdasarkan hasil uji secara parsial menunjukan bahwa Debt to Asset Ratio berpengaruh positif dan signifikan terhadap Divident Payout Ratio dan hasil penelitan ini tidak sejalan dengan teori Menurut Gumanti (2013:5), Perusahaan dengan leverage keuangan yang tinggi akan cenderung memiliki dividen yang rendah, karena jika dividen yang dibayarkan tinggi maka kondisi tersebut dapat dianggap bahwa perusahaan sudah menjanjikan komitmen baru yang secara financial tentu akan sangat mengganggu kestabilan keuangan perusahaan, khususnya beban biaya tetap. Hasil penelitian ini tidak sejalan dengan penelitian Maulidah, dkk (2015) yang menyatakan bahwa secara parsial Debt to Asset Ratio tidak berpengaruh signifikan terhadap Divident Payout Ratio. Pada penelitian ini secara parsial Debt to Asset Ratio berpengaruh positif dan signifikan terhadap Divident Payout Ratio. Ketika perusahaan memiliki leverage keuangan yang tinggi akan cenderung memiliki dividen yang rendah, karena jika dividen yang dibayarkan tinggi maka kondisi tersebut maka akan sangat mengganggu kestabilan keuangan perusahaan, khususnya beban biaya tetap. Berdasarkan hasil uji secara parsial menunjukan bahwa Current Ratio berpengaruh positif dan signifikan terhadap Divident Payout Ratio dan hasil penelitan ini sejalan dengan teori Menurut Horne \& Wachowicz (2010:282), likuiditas perusahaan 
yang diukur oleh Current Ratio merupakan pertimbangan utama dalam banyak keputusan dividen, karena apabila dividen menunjukkan arus kas keluar makin besar posisi kas dan keseluruhan likuiditas perusahaan, maka semakin besar kemampuan perusahaan untuk membayarkan dividen. Hasil penelitian ini sejalan dengan penelitian Maulidah, dkk (2015) yang menyatakan bahwa secara parsial Current Ratio berpengaruh positif signifikan terhadap Divident Payout Ratio. Pada penelitian ini secara parsial Current Ratio berpengaruh positif dan signifikan terhadap Divident Payout Ratio. Sehingga pada perusahaan sektor industri dasar dan kimia harus lebih memerhatikan likuiditas, posisi kas atau likuiditas dari suatu perusahaan merupakan faktor penting yang harus dipertimbangkan sebelum mengambil keputusan untuk menetapkan besarnya deviden yang akan dibayarkan kepada para pemegang saham. Disaat posisi likuiditas perusahaan semakin besar, berarti makin besar juga kemampuannya untuk membayar deviden. Berdasarkan hasil pengujian hipotesis secara simultan untuk variabel Returrn On Equity, Debt to Asset Ratio dan Current Ratio terhadap Divident Payout Ratio diperoleh nilai Fhitung adalah sebesar 15,641 dengan nilai signifikansi 0,000 sedangkan Ftabel adalah sebesar 2,73 dengan signifikansi 0,05. Dengan demikian maka kesimpulannya adalah Fhitung > Ftabel yaitu 15,641 > 2,73 maka keputusannya adalah H0 ditolak dan Ha diterima, artinya variabel Returrn On Equity, Debt to Asset Ratio dan Current Ratio secara simultan berpengaruh signifikan terhadap Divident Payout Ratio pada perusahaan sektor industri dasar dan kimia yang listing di Bursa Efek Indonesia periode $2013-2018$.

\section{KESIMPULAN}

Dari hasil penelitian ini diperoleh kesimpulan sebagai berikut:

1. Dari hasil pengujian yang dilakukan secara parsial Return On Equity tidak berpengaruh dan signifikan terhadap Devident Payout Ratio pada perusahaan sektor industri dasar dan kimia yang listing di Bursa Efek Indonesia periode 2013-2018. Hal ini dapat dilihat dari maka -thitung < -ttabel adalah $(-3,378<-1,99254)$ maka Ha ditolak dan $\mathrm{H} 0$ diterima.

2. Dari hasil pengujian yang dilakukan secara parsial Debt to Asset Ratio berpengaruh positif dan signifikan terhadap Devident Payout Ratio pada perusahaan sektor industri dasar dan kimia yang listing di Bursa Efek Indonesia periode 2013-2018. Hal ini dapat dilihat dari maka thitung > tabel adalah $(4,611>1,99254)$ maka Ha diterima dan H0 ditolak.

3. Dari hasil pengujian yang dilakukan secara parsial Current Ratio berpengaruh Positif dan signifikan terhadap Devident Payout Ratio pada perusahaan sektor industri dasar dan kimia yang listing di Bursa Efek Indonesia periode 2013-2018. Hal ini dapat dilihat dari maka thitung > tabel adalah $(5,400>1,99254)$ maka Ha diterima dan H0 ditolak.

4. Dari hasil pengujian yang dilakukan secara simultan Return On Equity, Debt to Asset Ratio dan Current Ratio berpengaruh dan signifikan terhadap Devident Payout Ratio pada perusahaan sektor industri dasar dan kimia yang listing di Bursa Efek Indonesia periode 2013-2018. Hal ini dapat dilihat dari nilai Fhitung > Ftabel $(15,641>2,73)$. Koefisien determinasi $\left(\right.$ Adjusted $\left.\mathrm{R}^{2}\right)$ sebesar 0,266 atau 26,6\% yang berarti perubahan variabel Devident Payout Ratio dapat dijelaskan oleh variabel Return On Equity, Debt to Asset Ratio dan Current Ratio.

\section{DAFTAR PUSTAKA}

Brigham, Eugene F. \& Joel F. Houston. (2015). Dasar-Dasar Manajemen Keuangan. Ed.11. Ceetakan ke-7 Jakarta: Salemba Empat

Fahmi, Irham. (2016). Pengantar Manajemen Keuangan: Teori dan Soal Jawab. Cetakan Kesatu. Anggota IKAPI. Bandung: CV. Alfabeta.

Ghozali, Imam. (2016). Aplikasi Analisis Multivariate dengan Program IBM SPSS 21. Semarang: Badan Penerbit Universitas Diponegoro

Gumanti, Tatang Ary. (2013). Kebijakan Dividen: Teori, Empiris dan Implikasi. Edisi Pertama. Yogyakarta: UPP STIM YKPN.

Hanafi, Mamduh M \& Abdul Halim. (2016). Analisis Laporan Keuangan. Ed. 5, Cetakan Ke-1. Yogyakarta: UPP STIM YKPN.

Harahap, Sofyan Syafri. (2015). Analisis Kritis atas Laporan Keuangan. Edisi 1. Cetakan ke- 
12. Jakarta: Rajawali Pers.

Hery. (2017). Analisis Laporan Keuangan. Cetakan Ke-2. Jakarta: PT. Grasindo. Horne, James C. Van \& John M. Wachowicz. (2013). Prinsip - Prinsip Manajemen Keuangan. Buku 1. Ed. 13, Jakarta: Salemba Empat.

Jumingan. (2011). Analisis Laporan Keuangan. Cetakan Keempat. Jakarta: PT. Bumi Aksara. Kasmir. (2012). Analisis Laporan Keuangan. Edisi I. Cetakan ke-5. Jakarta: Rajawali Pers.

Maulidah, Fitri dan Azhari Muhammad. (2015). "Pengaruh Return on Asset, Return On Equity, Debt to Total Asset Ratio, Growth dan Firm Size terhadap Dividend Payout Ratio (Studi pada Perusahaan BUMN yang Terdaftar di BEI Tahun 2009-2013)". e- Proceeding of Management. Vol.2. No.2. Desember. Hal: 2595-2602. ISSN: 2355- 9357.

Munawir. (2014). Analisa Laporan Keuangan, Cetakan Ke-17. Yogyakarta: Liberty. Murhadi, Werner R, (2015). Analisa Laporan Keuangan, Proyeksi dan Valuasi Saham. Jakarta: Salemba Empat.

Pamungkas, Noto., Rusherlistyani., Janah Isnatul. (2017). "Pengaruh Return On Equity, Return On Equity, Return On Equity, Earning Per Share dan Investment Opportunity Set terhadap Kebijakan Dividen”. Jurnal Analisa Akuntansi dan Perpajakan. Vol.1. No.1. Maret. Halaman: 34-41.

Raharjaputra, Hendra S. (2011). Buku Panduan Praktis Manajemen Keuangan dan Akutansi untuk Eksekutif Perusahaan. Cetakan Ke-1. Jakarta: Salemba Empat.

Riyanto, Bambang, (2010). Dasar-Dasar Pembelanjaan Perusahaan. Edisi 4, Cetakan Kelima. Yogyakarta: BPFE.

Sanusi, Anwar. (2011). Metode Penelitian Bisnis.Cetakan Ke-1. Jakarta: Salemba Empat. Sarmento, Jelmio Da Costa \& Dana Made. (2016). "Pengaruh Return On Equity, Return On Equity dan Earning Per Share terhadap Kebijakan Dividen pada Perusahaan Keuangan". E-Jurnal Manajemen Unud. Vol.5. No.7. Hal: 4224-4252. ISSN: 2302- 8912.

Sartono, Agus. (2010). Manajemen Keuangan Teori dan Aplikasi. Ed.4, Yogyakarta: BPFE Yogyakarta. Sudana, I Made. (2011). Manajemen Keuangan Perusahaan Teori dan Praktik. Surabaya: Erlangga.

Sugiyono. (2012). Metode Penelitian Bisnis. Cetakan Keenambelas. Bandung: Alfabeta

Sujarweni, Wiratna. (2015). Metodologi Penelitian Bisnis dan Ekonomi. Cetakan Ke-1. Yogyakarta: Pustaka Baru Press.

Sunyoto, Dadang. (2013). Dasar-Dasar Manajemen Keuangan Perusahaan. Cetakan Ke-1. Yogyakarta: CAPS.

Syamsuddin, Lukman. (2013). Manajemen Keuangan Perusahaan Konsep Aplikasi dalam Perencanaan,Pengawasan dan Pengambilan Keputusan. Ed. Baru, Cetakan Ke-12. Jakarta: Rajawali Pers.

www.idx.co.id

www.economy.okezone.com 